\title{
Dramatic Play In Relation To Self- Regulation In Preschool Age
}

\author{
Sama Khomais, King Abdulaziz University, Saudi Arabia \\ Naseima Al-Khalidi, King Abdulaziz University, Saudi Arabia \\ Duha Alotaibi, Taif University, Saudi Arabia
}

\begin{abstract}
This study aims to investigate the relationship between dramatic play and self-regulation in preschool age. The descriptive correlational methodology is utilized using three tools: dramatic play questionnaire, self-regulation scale (Head, Toes, Knees, and Shoulders), and children's interviews. The sample of the study consists of 60 children aged 4-6 years. Quantitative analysis is done using the Pearson Correlation Coefficient, factor analysis, and multiple regression analysis. The interviews with children are qualitatively analyzed calculating frequency, and percentage of coded data. The findings reveal a significant positive correlation between dramatic play and self-regulation. Besides, it is found that self-regulation could be predicted through the dimension of interactions with others during dramatic play. The study also proves a defect in the quality of dramatic play in terms of social interaction, symbolism, and themes and roles practiced by children. In the light of these results, the researchers suggest that mothers and teachers' awareness of the importance of quality dramatic play should be enhanced, to enable them to allow and plan for quality play. Also, allowing flexibility in preschool programs could support teachers' efforts in enhancing play engagement and development. Finally, this study has facilitated further research in the Arabian region, since it highlighted a valid, cross-cultural tool for measuring self-regulation in the Arabic language.
\end{abstract}

Keywords: Dramatic play; Self-regulation; Preschool; Saudi Arabia; HTKS; Play dimensions

\section{INTRODUCTION}

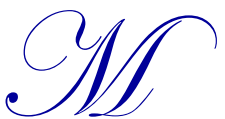

any educational theories are based on the fact that the first five years of children's lives are the most critical ones. Yet, some scholars believe that policymakers have recognized the importance of early development in this stage, but the role of play has been overlooked (Wood, 2013; Wood \& Hedges, 2016). Play, in general, is considered as the most important activity practiced by children, because it motivates their thinking and deepens their imagination, while dramatic play, in particular, is one of the most important types of play for preschoolers. According to Vygotsky (1978), this type of play could be distinguished by children's abilities of using things in a symbolic way, pretending through actions in imaginative situations, playing various roles through performing suitable interactions and dialogues, and merging different events in one-time frame, which may take place in days or weeks (Bodrova, 2008; Germeroth et al. 2019). While theories of human development suggest that dramatic play has an important role in growth, Vygotsky (1978) went beyond this by considering it as a vital factor in the growth and a unique dynamic in the development of self-regulation (Germeroth et al. 2019; Ogan, 2008).

On the other hand, self-regulation is considered as one of the main characteristics in early childhood for different reasons. Considering its three components; which are attention, working memory, and inhibitory control, selfregulation has been always linked to developmental outcomes (Bodrova \& Leong, 2007; Germeroth et al. 2019). Studies showed that it affects social efficiency, moral growth, and is considered as a predictive and decisive factor in school readiness, math and literacy skills, cognitive and academic performance, problem-solving, and decision making (Matthews, Ponitz \& Morrison, 2009; Neuenschwander, Rothlisberger, Cimeli \& Roebers, 2012; Schmitt, Pratt, \& McClelland, 2014; Sinha, 2012; Suchodoltz et al. 2013;). Even after controlling basic variables such as intelligence, age, and parents' education, self-regulation appears to be a strong predictor of school achievement. Children who can manage their ideas, feelings, and behaviors effectively can move easily between social and educative environment, while those who lack this ability are at risk of facing school failure and social and behavioral problems (Goldstein \& Lerner, 2018; McClelland \& Cameron, 2011). Moreover, different studies related the components of self-regulation 
to academic achievement. For instance, the ability to focus attention is found to be a predictor of achievement, while working memory is related to literacy and math skills (Becker, Miao, Duncan \& McClelland, 2014; Bohlmann \& Downer, 2016; Ivrendi, 2016; Suchodoletz et al. 2013). Inhibitory control plays a role in learning, since being in class requires inhibiting impulsive motor responses (Torres, 2011). It appears then that self-regulation enables children to adapt themselves successfully to the requirements of school classrooms. It makes academic achievement not only achievable but also distinguished in the coming stages.

The impact of dramatic play on self-regulation is based on Vygotsky's belief regarding the inherent relationship between the roles played by children and the rules they should follow during play activities or time to continue the game plot. This relationship requires children practicing self-regulation through regulating others. Therefore, Vygotsky (1978) considered dramatic play as the proper means to develop self-regulation skills (Bodrova, 2008; Bodrova, Leong, \& Akhutina, 2011; Germeroth et al. 2019; Ogan, 2008). Also, dramatic play enables children to play roles, create scenarios, and follow rules established by the players themselves. It allows them to pay attention and focus at high levels compared to undramatic situations (Ivrendi, 2016; Ogan, 2008; Savina, 2014; Slot, Mulder, Verhagen \& Leseman, 2017). Correspondingly, the quality of dramatic play showed to be a significant factor in developing self-regulation among preschoolers (Elis \& Berk, 2002; Slot et al. 2017). Also, Mathews (2008) found that there is a relationship between self-regulation, dramatic play, and school readiness. She found that dramatic play predicts children's ability to regulate themselves, while self-regulation predicts school readiness.

According to Bodrova and Leong (2007), dramatic play is a home-developed activity that transfers to the school. In the school context, children need social and cognitive support during dramatic play as a self-regulatory activity. The support can be provided through discussion, negotiation, suggestions, initiative independence, and through listing to their voices and opinions (Broekhuizen, Slot, van Aken \& Dubas, 2017; Kangas, Ojala \& Venninen, 2015). However, observations from the field in preschool centers classrooms reveal a decrease of dramatic play in quality and quantity, where the limited time devoted and materials and arrangements provided fail to develop a mature dramatic play. Therefore, and based on previous studies that proved relationships between quality dramatic play and self-regulation, this study intends to test the hypotheses of Vygotsky's theory, which has not been studied -to best of the knowledge of the researchers- in the Arabian region. The researchers intend to investigate the relationship between dramatic play and self-regulation within natural conditions at home settings that represent better circumstances compared to preschool centers, especially because of time and tools available, which allows for the emergence of quality dramatic play. Accordingly, the study aims to answer the following questions:

- What is the relationship between preschoolers' dramatic play and self-regulation?

- What is the possibility of having a predictive relationship between dramatic play and self-regulation at the preschool level?

\section{METHOD}

The correlative descriptive method was utilized to achieve the objectives of the study. The quantitative data collected from self-regulation scale and mothers' questionnaire were analyzed using correlation coefficient, factor analysis, and multiple regression analysis. The qualitative data from children's interviews were coded and grouped according to play dimensions, which are considered as an anticipatory grouping. Children's responses were organized in an "Informant-by-variable matrix" as the first step of the analysis to show similarities and differences. Afterward, the data were coded and regrouped in a "Conceptually clustered matrix", using frequencies and percentage (Miles \& Huberman, 1994).

\section{Sample}

The target population consisted of (2685) KG2 and KG3 preschoolers in (27) public preschool centers in the city of Makkah. The sample consisted of (60) children (31 boys and 29 girls) from (3) public preschool centers, which were selected intentionally from the middle district of Makkah city, to represent the population properly, since the urban areas of the city include citizens from different cultures. 


\section{Tools of the Study}

The study utilized three tools, which were dramatic play questionnaire, and self-regulation scale, in addition to children's interview.

\section{The Dramatic Play Questionnaire}

This questionnaire was designed as a tool to collect data about children's dramatic play from mothers. They were asked to observe their children while playing at home for at least one week before they start filling the questionnaire. A CD was attached with the questionnaire to clarify the specific procedures of observations, and the characteristics of dramatic play, through a video. The CD content was also available on a provided link on the internet.

The questionnaire was designed according to the following procedures:

A. Defining the sub-dimensions of the questionnaire and writing their statements after reading related previous studies such as Matthews (2008); Elias \& Berk (2002). Accordingly, it consisted of the following dimensions:

1. Symbolic actions and tools: it refers to the symbolic usage of actions and tools during play. They are considered symbolic when tools are used for purposes other than their real functions, and when actions are imaginative, where a child imagines himself doing realistic or unrealistic actions.

2. Using language to create an imaginative scenario: it refers to using language as a communication means between a child and playmates. This dialogue is about play plot and its tools and may be used as a dialogue between the different characters in the scenario.

3. Complex and interrelated topics: it refers to combining two or more topics during play while integrating many tools, ideas, and characters without stopping the scenario of play.

4. Rich multiple roles: it refers to the child's total projection of the characters; their roles, movements, voices, clothes, and tools. The child may be performing more than one character at the same time.

5. Interaction with others: it refers to playing with at least one character, either a toy or a person, and exchanging roles and dialogues with them.

6. Extension of time frame: it refers to the continuity of play without intervals, for not less than $5 \mathrm{~min}$. The child may also continue playing on the same topic for more than one day by adding new ideas, tools or characters.

B. The content validity of the questionnaire was checked by arbitrators, who are university professors of childhood studies and psychology at different Saudi Arabian universities.

C. The questionnaire was piloted with a sample of (15) mothers of KG2 and KG3 preschoolers, from Makkah city, to make sure that the statements of the questionnaire are clear and not ambiguous.

D. The internal consistency of the questionnaire was also checked, and it showed good Cronbach alpha coefficient of (0.827).

\section{Self-Regulation Scale}

Head-Toes-Knees-Shoulders (HTKS) (Ponitz et al. 2008) is a known scale that measures self-regulation through children's performance when asked to touch the opposite part of their body parts (head, toes, knee, and shoulder) according to specific instructions.

To be applicable for the study, it was translated into Arabic language using translation- back-translation procedures. The first and second authors of this article have conducted the translation procedures, after having permission from the designers of the scale.

Even though the validity and reliability of the scale had been confirmed by its designers, the feasibility of the Arabic version of the scale was ensured by the following steps: 
- Piloting: the scale was piloted on 15 children observing their responses to confirm that they understand the instructions and the statements included.

- Calculating the reliability of scale: the scale was applied to a sample of (25) children (other than the study sample), and then it was applied again after two weeks. The reliability was calculated using Pearson correlation coefficient, which showed a strong and significant correlation, $r=.929, n=25, p<.01$.

\section{Children's Interview}

The interview questions were prepared in light of the dimensions of dramatic play to add a deeper understanding of the quality of children performs during their dramatic play. According to the different levels shown in self-regulation scores (low, average and high scores), 18 children were randomly selected from each level for the interview. The interviews were tape-recorded, for later transcribing and analysis.

\section{RESULTS}

\section{Dramatic Play and Self-Regulation}

The correlation between dramatic play and self-regulation was investigated using Pearson correlation coefficient. Preliminary analyses were performed to ensure no violation of assumptions of normality, linearity, and homoscedasticity. The analysis showed that there is a positive significant correlation between the two variables, $r=$ $.262, n=60, p<.05$. Table 1 shows descriptive statistics of dramatic play and self-regulation.

Table 1. Descriptive statistics of dramatic play and self-regulation.

\begin{tabular}{l|c|c|c}
\hline \multicolumn{1}{c}{ Variable } & N & Mean & Std. Deviation \\
\hline Dramatic Play & 60 & 166.6 & 24.34 \\
\hline Self-regulation Score & 60 & 38.13 & 13.12 \\
\hline
\end{tabular}

To determine the dimensions that mostly affect the questionnaire outcomes, the items under each play dimension were subjected to principle component analysis (PCA). Before performing PCA the suitability of data for factor analysis was assessed. Principle component analysis revealed the presence of one component with eigenvalue exceeding 1 , explaining 56.186 of the variances. To aid in the interpretation of this component, Varimax rotation was performed using Kaiser Criterion. As shown in Table 2, the dimension of "Rich multiple roles" was the most to affect the questionnaire outcomes, while "interaction with others" was the least.

Table 2. Component Matrix for PCA with Varimax rotation of one Factor solution of play dimensions

\begin{tabular}{|l|c|c|c|c|c|c|}
\hline Play dimensions & $\begin{array}{c}\text { Rich multiple } \\
\text { roles }\end{array}$ & $\begin{array}{c}\text { Complex and } \\
\text { interrelated } \\
\text { topics }\end{array}$ & $\begin{array}{c}\text { Using language } \\
\text { for pretending }\end{array}$ & $\begin{array}{c}\text { Time frame } \\
\text { span }\end{array}$ & $\begin{array}{c}\text { Symbolic } \\
\text { actions and } \\
\text { tools }\end{array}$ & $\begin{array}{c}\text { Interaction with } \\
\text { others }\end{array}$ \\
\hline Factor analysis & 0.857 & 0.853 & 0.756 & 0.723 & 0.667 & 0.608 \\
\hline
\end{tabular}

To test the dramatic play dimensions that predict self-regulation; Multiple Regression analysis was conducted. The dependent variable was self-regulation and the independent variable were dramatic play dimensions, while age groups and gender were controlled.

The results showed that the only dimension that could significantly predict self-regulation score is "interaction with others", while other dimensions were not statistically significant predictors. As shown in Table $3, R^{2}=0.096, F(1,58)$ $=6.188, p<.05$, which means that $9.6 \%$ of self-regulation score could be predicted by the interaction with others, while the remaining could be referred to other factors. 
Table 3. Multiple Regression Analysis of Dramatic Play Dimension “interaction with others" as a Predictor of Self-regulation.

\begin{tabular}{c|c|c|c|c|c|c|}
\hline $\begin{array}{c}\text { Regression } \\
\text { Coefficient }\end{array}$ & Constant & $\begin{array}{c}\text { Interaction with } \\
\text { others }\end{array}$ & R & R Square & F & Sig. \\
\hline B & 6.056 & 0.961 & 0.310 & 0.096 & 6.188 & $.016^{*}$ \\
\hline Beta & & 0.310 & $0.58)$ & $(1,58)$ \\
\hline
\end{tabular}

\section{Children's interviews}

For more insights into the quality of dramatic play practiced, an interview with (18) of the children from the sample was conducted. According to the questions and children's responses, the qualitative analysis included six anticipatory groups, which are based on play dimensions. The groups are symbolic actions, symbolic props, language, themes, roles, and interaction. Each of these groups was coded as shown in Table 4.

Table 4. Children's Interviews outcomes

\begin{tabular}{|c|c|c|c|c|}
\hline & & & $\begin{array}{l}\text { Frequency } \\
(N=18)\end{array}$ & $\begin{array}{l}\text { Percentage of tota } \\
\text { Responses }\end{array}$ \\
\hline \multirow{2}{*}{ Symbolic Actions } & \multicolumn{2}{|l|}{ Real } & 18 & 100 \\
\hline & \multicolumn{2}{|c|}{ Unreal (Cartoons) } & 4 & 22.2 \\
\hline \multirow{3}{*}{ Symbolic Props } & \multicolumn{2}{|c|}{ Symbolic } & 5 & 27.7 \\
\hline & \multirow{2}{*}{ Unsymbolic } & Ready Made Props & 17 & 94.4 \\
\hline & & From Home Props & 4 & 22.2 \\
\hline \multirow{2}{*}{ Language } & \multicolumn{2}{|c|}{ Towards self } & 10 & 55.5 \\
\hline & \multicolumn{2}{|c|}{ Towards others (persons or toys) } & 18 & 100 \\
\hline \multirow{2}{*}{ Themes } & \multicolumn{2}{|c|}{ Integrating themes } & 0 & 0 \\
\hline & \multicolumn{2}{|c|}{ Integrating characters } & 18 & 100 \\
\hline \multirow{3}{*}{ Roles } & \multicolumn{2}{|c|}{ Multi-role } & 5 & 27.7 \\
\hline & \multirow{2}{*}{ Pretending } & Voice Actions & 17 & 94.4 \\
\hline & & Clothes & 2 & 11 \\
\hline \multirow{3}{*}{ Interaction } & \multirow{2}{*}{ Share Play } & With others & 16 & 88.8 \\
\hline & & With toys & 5 & 27.7 \\
\hline & \multicolumn{2}{|c|}{ Alternate roles } & 8 & 44.4 \\
\hline
\end{tabular}

\section{DISCUSSION}

This study aimed to investigate the association between dramatic play and self-regulation. The results showed that there is a positive significant correlation between the two variables. The results also showed that only the dimension "interaction with others" could predict self-regulation score, while other dimensions were not statistically significant predictors.

In the review of several studies, Whitebread, Coltman, Jameson and Lander (2009) suggested supporting children's self-regulated learning through the encouragement of playful activities in educational contexts. They signified principles of activities that consider emotional warmth, children's initiation and feelings of control, cognitive challenge through problem solving and creativity, and use of language, which all apply to productive play, which includes dramatic play in particular. Other studies confirmed the importance of a supportive social and cognitive environment during dramatic play as self-regulatory activity (Broekhuizen et al. 2017; Kangas et al. 2015). Therefore, the correlation shown between self-regulation and dramatic play in the current study could be explained through this perspective. It also confirms the outcomes of similar descriptive studies, which investigated the same variables (Elias \& Berk, 2002; Li, 2012; Matthews, 2008; Neitzel, 2003; Polnariev, 2006; Slot et al. 2017). Cemore and Herwig (2005) also found that dramatic play at home positively affects inhibitory control, which is one of the three components of self-regulation. Other experimental studies have shown this relationship by utilizing dramatic play in intervention programs. These studies confirmed that practicing dramatic play improves self-regulation skills (Goldstein \& Lerner, 2018; Ogan, 2008; Sinha, 2012). 
Although the correlation coefficient revealed in the current study is close to the ones found in some other similar studies (Elias \& Berk, 2002; Matthews, 2008), it is of low level. In an endeavor to find some explanations, it appeared that they could be sought through investigating the quality of dramatic play children were practicing.

The outcomes of our study showed that the only dimension in play that could predict self-regulation is "interaction with others". Polnariev (2006) clarified that playing with others requires advanced self-regulation skills to keep the play plot going flexible without disruption. It specifically requires inhibitory control skills that guarantee effective collaboration between players to reach their mutual goals. Engaging in social play requires not only to regulate own thinking and behavior but to understand and regulate co-players thinking to maintain the collaborative situation (Whitebread, 2010; Whitebread \& O'Sullivan, 2012). In fact, Elias \& Berk (2002) found that high-impulsive preschoolers benefit from complex Scio-dramatic play since they need to inhibit impulse in favor of following social rules inherent in dramatic play, while the solitary play has negatively associated with self-regulatory development. Li (2012) and Ivrendi (2016) have also found similar results.

In spite of the evident relation between socio-dramatic play and self-regulation development, the factor analysis of paly dimensions showed that the least dimension that affects the outcomes of mother's responses about children's play was "Interaction with others". It means that most of the children's play was not described as social, which includes interaction with other children, although it is the play dimension that significantly predicts self-regulatory development, as revealed by Regression Analysis. However, $88.8 \%$ of the interviewed children expressed that they were playing with others. Nevertheless, most of the mothers' responses on this dimension confirmed that their children do not have opportunities to play with others except by end of the week during family or friend gatherings, which explained children's responses and confirmed the weakness of interactions with others during play. Also, $27.7 \%$ of the interviewed children expressed that they share play with toys as characters, which confirms the absence of play partners. Accordingly, since the predicting dimension did not appear strongly in children's play, this might explain the weak correlation between dramatic play and self-regulation revealed in this study. It might also justify the low prediction score of "interaction with others" revealed from Multiple Regression Analysis.

Unfortunately, other aspects of play appeared to be weak in form and content. Children's interviews revealed that children's play did represent sufficient symbolic actions, props, and use of clothes to characterize roles. For instance, $22.2 \%$ of the children described playing unreal actions, at the same time; all of them expressed practicing real actions during play. Additionally, $22.2 \%$ of the interviewed children stated that they were allowed to use home materials or furniture as props for the play. The remaining children explained either that they do not use home materials, or they are not allowed to use them. They mentioned some justifications such as that they "prefer to play neatly", or their "mother likes the house to be neat and clean", while other expressed being rebuked for using house materials for play. Alternatively, $94.4 \%$ of the children stated that they play with ready-made props that represent their ideas in the plot, while $27.7 \%$ use symbolic props from their toys to symbol what they have in mind. Fortunately, pretending voices and actions and using language were highly shown in children's responses.

On the other hand, the idea of pretending wearing clothes that represent roles seemed to be unclear for children since $11 \%$ of them only stated that they pretend wearing clothes of characters, while the remaining children stated that they do not have these clothes, or they have to buy them. These responses showed that children did not realize the symbolism in pretending wearing clothes even after explained by the researcher.

Limitations in themes and roles were also shown through interviews. Children's responses revealed that none of them integrates themes, which means that they always play within one theme (i.e. clinic or supermarket ... etc.) and do not integrate themes (i.e. the physician in the clinic goes to the supermarket to buy some goods for home). Unfortunately, integrating themes is considered as one of the important aspects of mature play (Bodrova, 2008; Germeroth et al. 2019). Also, only $27.7 \%$ of the children pretend multi-roles at the same time of play, while others do not; they stick to one role during the play plot. On the other hand, although all children said that they accept to integrate new partners if they found ones to join play, $44.4 \%$ of the children expressed that they do not like to alternate roles, as they prefer to take the strongest or the dominant character (Physician not patient, police officer not thief, Ben10 not monster). These preferences explicate that children were not capable of compromising with others to keep the play plot going. This behavior appears to have a negative effect on following the rules of pretend play established by players themselves, which plays an important role in self-regulation development (Bodrova \& Leong, 2007). 
Although the interview was conducted with a limited number of children from the sample, it revealed valuable information about the quality of play, considering interaction, symbolism, themes and roles included in pretend play. Bodrova, Germeroth, and Leong (2013) mentioned that pretend play has decreased in quality and quantity, where children tend to play with real materials, practicing same scenarios, within a limited number of themes and roles.

\section{Practical Implications}

In spite of the shown insufficient quality of dramatic play, the study revealed an association between it and selfregulation. Previous studies have also confirmed this relation, thus, improving the quality of play is of the most important aspects that should be taken into account as a base for the development of self-regulated behavior. The quality of dramatic paly is affected by different dynamics including the availability of open-ended materials that encourage symbolic usage and actions, and variability of experiences that enrich children's background to develop own themes and roles. Interaction with other children is evident to be a valuable dimension, which helps them tolerate working with others by practicing inhibitory control and to support the use of language as an expressive means of thoughts and feelings. Therefore, awareness of the importance of quality dramatic play and factors affect it should be enhanced among mothers and teachers, by enabling them to allow and plan for quality play. The time allowed for play is also a significant factor, which is usually decreased, especially at schools, where fixed schedules are to be followed. Therefore, providing flexibility in preschool programs could help improve the quality of play, and support teachers' efforts in enhancing play engagement and development. Practicing quality dramatic play would enhance working memory, attention, and inhibitory control, which would all result in advanced self-regulation.

\section{Limitations and Future Research}

The number of the sample might be one of the most important limitations in this study. Further research with a larger number of participants and from different settings and backgrounds, could have significant outcomes about the relation between dramatic play and self-regulation. Other sources of limitation in this study could be the methods used to gather information about the dramatic play at home, using mothers' questionnaire. Although we did our best to ensure the validity of this data, we believe that using other tools such as video tapping would have provided much valid information. However, that was not possible due to cultural constraints. Therefore, we tried to gain a better understanding by children's interviews. Nevertheless, we still encourage studying play in different settings that may allow using more valid tools, if it is possible. Using different research tools could also facilitate studying the quality of dramatic play and the factors that affect it in home and preschool settings, which should be subject to research and improvement. On the other hand, measuring self-regulation has become much possible through HTKS, which allows for further research in this area from different perspectives.

\section{CONCLUSION}

The outcomes of the study provided insights into the relationship between dramatic play and self-regulation, although the association has not been strongly proved, due to potential defects revealed in the quality of dramatic play. However, this study has opened the doors for further research in the Arabian region, since it highlights a valid, cross-cultural tool for measuring self-regulation in the Arabic language. On the other hand, this study had concentrated on one dynamic that could affect the development of self-regulated behavior, while all other factors are open for research, considering its evident importance in school successes, academic achievement, and lifelong accomplishments.

\section{AUTHOR BIOGRAPHIES}

Sama Khomais, Assistant Professor, Childhood Studies Department in KAU, Saudi Arabia. Earned her Ph.D. from the University of Exeter (UK) in Early Childhood Education (ECE). A member of the academic committee supervising program implementation and teaching practices in the Childhood Center at the university serving children birth to six. Has special research interests in mathematics and science content and pedagogies for preschool children, effective learning environments, and play for learning. Email: skhomais@kau.edu.sa

Naseima Al-Khalidi, Assistant Professor at Childhood Studies Department in KAU, Saudi Arabia. Has a Ph.D. in Curricula and Instruction. She served as a consultant and coordinator for Queen Rania Teacher Training Academy, 
and supervisor of English training/trainer for the Directorate of Training Qualification and Supervision in The Jordanian Ministry of Education. Her research interests include human rights in the curricula, feminism and curriculum, gender reform in curricula, women education and empowerment. E-mail: Nisma.alkhalidi@gmail.com

Duha Alotaibi, a Ph.D. student in learning psychology. Alotaibi has earned her master's degree in education from childhood studies department in KAU. She works as a lecturer at the early childhood department in Taif University, Saudi Arabia since 2008. Technology is at the top of her interests. She has a comprehensive knowledge of E-learning concepts and familiarity with educational applications. Her research area focusses on early childhood cognitive psychology. E-mail: d-alaboud@tu.edu.sa

\section{REFERENCES}

Becker, D. R., Miao, A., Duncan, R., \& McClelland, M. M. (2014). Behavioral self-regulation and executive function both predict visuomotor skills and early academic achievement. Early Childhood Research Quarterly, 29, 411-424. http://dx.doi.org/10.1016/j.ecresq.2014.04.014.

Bodrova, E. (2008). Make-believe play versus academic skills: A Vygotskian approach to today's dilemma of early childhood education. European Early Childhood Education Research Journal, 16, 357-369. https://doi.org/10.1080/13502930802291777

Bodrova, E., \& Leong, D. J. (2007) Tools of the Mind: The Vygotskian Approach to Early Childhood Education. ( $2^{\text {nd }}$ ed). New Jersey: Pearson Prentice Hall.

Bodrova, E., Germeroth, C., \& Leong, D. J. (2013). Play and self-regulation: Lessons from Vygotsky. American Journal of Play, 6, 111-123. https://files.eric.ed.gov/fulltext/EJ1016167.pdf.

Bodrova, E., Leong, D. J., \& Akhutina, T. V. (2011). When everything new is well-forgotten old: Vygotsky/Luria insights in the development of executive functions. In R. M. Lerner, J. V. Lerner, E. P. Bowers, S. Lewin-Bizan, S. Gestsdottir, \& J. B. Urban (Eds.), Thriving in childhood and adolescence: The role of self-regulation processes. New Directions for Child and Adolescent Development, 133, 11-28. https://doi.org/10.1002/cd.301.

Bohlmann, N. L., \& Downer, J. T. (2016). Self-Regulation and Task Engagement as Predictors of Emergent Language and Literacy Skills. Early Education and Development, 27(1), 18-37. http://dx.doi.org/10.1080/10409289.2015.1046784.

Broekhuizen, M. L., Slot, P. L., van Aken M. A. G., \& Dubas, J. S. (2017). Teachers' Emotional and Behavioral Support and Preschoolers'Self-Regulation: Relations With Social and Emotional Skills During Play. Early Education and Development, 28(2), 135-153. http://dx.doi.org/10.1080/10409289.2016.1206458.

Carlson, S. M., \& Taylor, M. (2005). Imaginary companions and impersonated characters: Sex differences in children's fantasy play. Merrill-Palmer Quarterly, 51,93-118. http://dx.doi.org/10.1353/mpq.2005.0003.

Cemore, J. J., \& Herwig, J. E. (2005). Delay of gratification and make-believe play of preschoolers. Journal of Research in Childhood Education, 19, 251-266. https://doi.org/10.1080/02568540509595069.

Elias, C. L., \& Berk, L. E. (2002). Self-regulation in young children: Is there a role for sociodramatic play? Early Childhood Research Quarterly, 17, 216-238. http://dx.doi.org/10.1016/S0885-2006(02)00146-1.

Germeroth, C., Bodrova, E., Day-Hess, C., Barker, J., Sarama, J., Clements, D. H., \& Layzer, C. (2019). Play it High, Play it Low: Examining the Reliability and Validity of a New Observation Tool to Measure Children's Make-Believe Play. American Journal of Play, 11(2), 183-221. https://www.journalofplay.org/sites/www.journalofplay.org/files/pdfarticles/11-2-Article\%203.pdf.

Goldstein T. R., Lerner M.D. (2018). Dramatic pretend play games uniquely improve emotional control in young children. Developmental Science, 21, 1-13. https://doi.org/10.1111/desc.12603.

Ivrendi A. (2016). Choice-driven peer play, self-regulation and number sense. European Early Childhood Education Research Journal, 24(6), 895-906. http://dx.doi.org/10.1080/1350293X.2016.1239325.

Kangas J., Ojala, M., \& Venninen T. (2015). Children's Self-Regulation in the Context of Participatory Pedagogy in Early Childhood Education. Early Education and Development, 26, 847-870. https://doi.org/10.1080/10409289.2015.1039434.

Li, J. (2012). Preschoolers' outdoor pretend play and social competence: Do individual and home factors play a role? (Master thesis). Retrieved from ProQuest Dissertations \& Theses database. (UMI No. 1531954). http://search.proquest.com/docview/1284154656?accountid=142908.

Matthews, J., Ponitz, C., \& Morrison, F. (2009) Early Gender Differences in Self-Regulation and Academic Achievement, Journal of Educational Psychology, 101, 689-704. http://dx.doi.org/10.1037/a0014240.

Matthews, S. B. (2008). The relationship among self-regulation, sociodramatic play, and preschoolers' readiness for kindergarten (Doctoral dissertation). Retrieved from ProQuest Dissertations \& Theses database. (UMI No. 3338871). http://search.proquest.com/docview/287937638?accountid=142908.

McClelland, M. M., \& Cameron, C. E. (2011). Self-regulation and academic achievement in elementary school children. New Directions for Child and Adolescent Development, 133, 29-44. https://doi.org/10.1002/cd.302.

Miles, M. B., \& Huberman, A. M. (1994) Qualitative data analysis, (2nd Ed.). Thousand Oaks: Sage Publications. 
Neitzel, C. L. (2003). When predisposition meets opportunity: Children's early play interests and subsequent academic self regulatory behaviors in kindergarten (Doctoral dissertation). Retrieved from ProQuest Dissertations \& Theses database. (UMI No. 3111910). http://search.proquest.com/docview/305335018?accountid=142908.

Neuenschwander, R., Röthlisberger, M., Cimeli, P., \& Roebers, C. M. (2012). How do different aspects of self-regulation predict successful adaptation to school? Journal of Experimental Child Psychology, 113, 353-371 http://dx.doi.org/10.1016/j.jecp.2012.07.004.

Ogan, A. T. (2008). An investigation of the effects of make-believe play training on the development of self-regulation in head start children (Doctoral dissertation). Retrieved from ProQuest Dissertations \& Theses database. (UMI No. 3353104) $\mathrm{http}: / /$ search.proquest.com/docview/304606856?accountid=142908.

Polnariev, B. A. (2006). Dynamics of preschoolers self-regulation: Viewed through the lens of conflict resolution strategies during peer free - play (Doctoral dissertation). Retrieved from ProQuest Dissertations \& Theses database. (UMI No. 3241978) http://search.proquest.com/docview/305352827? accountid=142908.

Ponitz, C. C., McClelland, M. M., Jewkes, A. M., Connor, C. M., Farris, C. L., \& Morrison, F. J. (2008). Touch your toes! Developing a direct measure of behavioral regulation in early childhood. Early Childhood Research Quarterly, 23, 141-158 https://doi.org/10.1016/j.ecresq.2007.01.004 .

Savina, E. (2014). Does play promote self-regulation in children? Early Child Development and Care, 11, $1692-1705$. https://doi.org/10.1080/03004430.2013.875541

Schmitt, S. A., Pratt, M. E., \& McClelland, M. M. (2014). Examining the Validity of Behavioral Self-Regulation Tools in Predicting Preschoolers' Academic Achievement. Early Education and Development, 25(5), 641-660. https://doi.org/10.1080/10409289.2014.850397

Sinha, J. M. (2012). The land of make-believe: Using sociodramatic play to increase kindergartners' self-regulatory abilities (Doctoral dissertation). Retrieved from ProQuest Dissertations \& Theses database. (UMI No. 3544140). http://search.proquest.com/docview/1220844856?accountid=142908

Slot P.L., Mulder H., Verhagen J., \& Leseman P.P.M. (2017). Preschoolers' cognitive and emotional self-regulation in pretend play: Relations with executive functions and quality of play. Inf Child Development, 26, 1-21. https://doi.org/10.1002/icd.2038

Suchodoletz, A. V., Gestsdottir, S., Wanless, S. B., McClelland, M. M., Birgisdottir, F., Gunzenhauser, C., \& Ragnarsdottir, H. (2013). Behavioral self-regulation and relations to emergent academic skills among children in Germany and Iceland. Early Childhood Research Quarterly,28, 62-73. https://doi.org/10.1016/j.ecresq.2012.05.003

Torres, M. M. (2011). Understanding self-regulation: links to school readiness, and implications for intervening with high-risk children (Doctoral dissertation). Retrieved from ProQuest Dissertations \& Theses database. (UMI No. 3483744). http://search.proquest.com/docview/902153820?accountid=142908

Vygotsky, LS. (1978). Mind in Society: The Development of Higher Psychological Processes. Cambridge: MA: Harvard University Press.

Whitebread, D. \& O'Sullivan, L. (2012). Preschool children's social pretend play: supporting the development of metacommunication, metacognition and self-regulation. International Journal of Play, 1, (2), 197-213. https://doi.org/10.1080/21594937.2012.693384

Whitebread, D. (2010). Play, metacognition and self-regulation. In P. Broadhead, J. Howard, \& E. Wood (Eds.), Play and learning in the early years (pp. 161-176). London, UK: Sage.

Whitebread, D., Coltman, P., Jameson, H. \& Lander, R. (2009) Play, Cognition and Self-Regulation: What Exactly are Children Learning When They Learn Through Play? Educational \& Child Psychology, 26, 40-52.

Wood, E. (2013). Play, Learning and the Early Childhood Curriculum ( $3^{\text {rd }}$ Ed.) London: Sage Publications.

Wood, E., \& Hedges H. (2016). Curriculum in early childhood education: critical questions about content, coherence, and control. The Curriculum Journal, 27(3), 387-405. http://dx.doi.org/10.1080/09585176.2015.1129981. 
NOTES 